\title{
Chiasma counts and non-disjunction frequencies in a normal ram and in rams carrying the Massey $I\left(t_{1}\right)$ Robertsonian translocation
}

\author{
Susan E. Long* \\ Department of Reproduction, University of Glasgow, Veterinary School, Bearsden Road, \\ Bearsden, Glasgow, U.K.
}

\begin{abstract}
Summary. Testicular material from a normal ram (54XY), three rams heterozygous $\left(53 \mathrm{XYt}_{1}\right)$ and one ram homozygous $\left(52 \mathrm{XYt}_{1} \mathrm{t}_{1}\right)$ for the Massey $\mathrm{I}\left(\mathrm{t}_{1}\right)$ translocation was examined. The autosomal non-disjunction in the normal ram was $2.0 \%$ compared to a mean of $6.1 \%$ in the heterozygous animals. In the homozygous animal there were adhesions of the tunica vaginalis to the cauda epididymidis and extensive spermatogenic arrest.
\end{abstract}

\section{Introduction}

Detailed examination of meiosis in rams has been lacking until recently. Loir (1971) gave a brief morphological description of bivalents at diakinesis but did not analyse second metaphase figures. More detailed studies have been made by Bruère \& Chapman (1974) and Chapman \& Bruère (1975). These workers were particularly interested in meiosis in rams with one or more Robertsonian translocations. The present paper presents the results of examination of meiosis in animals carrying the Massey I $\left(\mathrm{t}_{1}\right)$ centric fusion (Robertsonian) translocation and compares them with meiosis in a normal ram.

\section{Materials and Methods}

Material was obtained from one normal ram $\left(F_{1} 199\right)$, three rams $\left(F_{1} 49, F_{1} 101\right.$ and $\left.F_{1} 113\right)$ heterozygous for the Massey I $\left(t_{1}\right)$ translocation and one ram $\left(F_{2} 200\right)$ homozygous for the Massey I $\left(t_{1}\right)$ : their ages were respectively $12,24,19,15$ and 12 months. Rams $F_{1} 199$ and $F_{2} 200$ were sampled during May, the period of the year when spermatogenic activity in rams is lowest; the others were examined during the peak of the breeding season. All the animals were the offspring of Scottish Blackface ewes $(54 X X)$ and New Zealand Romney rams $\left(53 X \mathrm{Yt}_{1}\right)$ except Ram $\mathrm{F}_{2} 200$ which was the offspring of this $F_{1}$ generation.

Material was obtained from testes removed under local anaesthesia. The method used for meiotic preparations was that developed by Logue (1975) for use in the bull. Single cell suspensions were obtained by using hypotonic solutions of $1 \%(\mathrm{w} / \mathrm{v})$ sodium citrate and $0.5 \%(\mathrm{w} / \mathrm{v})$ potassium chloride, and approximately $0.25 \mathrm{ml}$ of the fixed cell suspension was dropped onto a clean, cold, wet slide. The slides were stained in Giemsa in water $(1: 10 \mathrm{v} / \mathrm{v})$ for $5 \mathrm{~min}$ or in $2 \%$ aceto-orcein for $3 \mathrm{~h}$.

Samples were also taken from the testes for histological examination. The material was fixed in Bouin's fluid for 3 days and sections cut at $5 \mu \mathrm{m}$ were stained with haematoxylin and eosin.

Calculations of non-disjunction at meiotic metaphase II were made as follows:

Percentage non-disjunction (ND) $=\frac{\text { no. of hyperhaploid cells } \times 2 \times 100}{\text { total no. of cells counted }}$

This definition, used by Cattanach \& Moseley (1973), assumed that the number of hypohaploid and hyperhaploid cells, caused by non-disjunction, was equal and that hypohaploid cells in excess of the number of hyperhaploid cells were technical artefacts.

* Present address: Department of Animal Husbandry, University of Bristol, Langford House, Langford, Bristol BS18 7DU, U.K. 


\section{Results}

Histological examination of the testes of Rams $F_{1} 199, F_{1} 49, F_{1} 101$ and $F_{1} 113$ showed normal spermatogenesis throughout. Ram $F_{2} 200$ had some degree of spermatogenic arrest in all the tubules examined in both testes. Spermatogonia types A and B (Cole \& Cupps, 1959) and primary spermatocytes were identifiable but there were very few developing spermatids and even fewer spermatozoa. Spermatozoa were absent from the epididymis on the left side but some were present in the right epididymis.

In addition to the histological abnormalities, both testes of Ram $F_{2} 200$ exhibited adhesions of the tunica vaginalis to the cauda epididymidis. The adhesions extended over the whole of one-half of the cauda and when reflected the line of attachment ran dorso-ventrally.

In the pachytene spreads the sex vesicle was easily identified as a small, darkly staining body. The acrocentric bivalents could not be individually identified. The three metacentric bivalents were the largest bivalents but again were not individually identified. Thirty-three cells in late diplotene or diakinesis were selected from the normal ram $\left(F_{1} 199\right)$ for photography and karyotyping (Pl. 1, Fig. 1). Each cell contained 26 autosomal bivalents plus the $\mathrm{X}-\mathrm{Y}$ bivalent. The latter was always less darkly stained than the autosomal bivalents and was characterized by an elongated configuration, indicating an end-to-end association. It was not possible to determine which ends of the $\mathrm{X}$ and $\mathrm{Y}$ chromosomes were associated. The autosomal chiasma counts are shown in Table 1 . In the three metacentric bivalents the number of chiasmata ranged from 4 to 8 and in the acrocentric bivalents from 1 to 3 .

Table 1. Mean chiasma frequencies ( \pm s.d.) of rams homozygous and heterozygous for the $t_{1}$ translocation compared with a normal ram

\begin{tabular}{lcccccc}
\hline Ram & $\begin{array}{c}\text { No. of } \\
\text { cells }\end{array}$ & $\begin{array}{c}\text { Metacentric } \\
\text { bivalents }\end{array}$ & Trivalent & $\begin{array}{c}\text { Translocation } \\
\text { bivalent }\end{array}$ & $\begin{array}{c}\text { Acrocentric } \\
\text { bivalents }\end{array}$ & Total \\
\hline$F_{1} 199$ & 33 & $14 \cdot 9 \pm 3 \cdot 5$ & - & - & $38 \cdot 9 \pm 4 \cdot 9$ & $54 \cdot 3 \pm 6 \cdot 4$ \\
$F_{1} 49$ & 11 & $14 \cdot 6 \pm 4 \cdot 9$ & $3 \cdot 1 \pm 0 \cdot 4$ & - & $37 \cdot 8 \pm 3 \cdot 2$ & $56 \cdot 3 \pm 5 \cdot 2$ \\
$F_{1} 101$ & 19 & $14 \cdot 3 \pm 4 \cdot 1$ & $2 \cdot 9 \pm 0 \cdot 4$ & - & $33 \cdot 8 \pm 4 \cdot 5$ & $51 \cdot 7 \pm 4 \cdot 6$ \\
$F_{1} 113$ & 7 & $16 \cdot 1 \pm 6 \cdot 7$ & $3 \cdot 4 \pm 0 \cdot 7$ & - & $37 \cdot 5 \pm 5 \cdot 0$ & $59 \cdot 4 \pm 6 \cdot 1$ \\
$F_{2} 200$ & 16 & $13 \cdot 0 \pm 3 \cdot 7$ & - & $3 \cdot 8 \pm 0 \cdot 6$ & $32 \cdot 0 \pm 4 \cdot 6$ & $49 \cdot 7 \pm 6 \cdot 2$ \\
\hline
\end{tabular}

One hundred cells in second metaphase (Pl. 1, Fig. 2) were counted (Table 2) and 35 were photographed and karyotyped. One spread had both an X and $Y$ chromosome (Pl. 1, Fig. 3). The sex chromosomes were usually easily identified by their slight negative heteropycnosis and the $\mathrm{X}$ by the reduction of chromatid repulsion. The $X$ and $Y$ segregation was not statistically significantly different from a $1: 1$ ratio $\left(\chi^{2}=2 \cdot 9 ; 0 \cdot 05<P<0 \cdot 1\right)$.

Table 2. Distribution of chromosome number at meiotic second metaphase in rams homozygous and heterozygous for the $t_{1}$ translocation compared with a normal ram

\begin{tabular}{|c|c|c|c|c|c|c|c|c|c|c|c|c|c|c|c|c|c|}
\hline \multirow[b]{3}{*}{ Ram } & \multirow{3}{*}{$\begin{array}{c}\text { Diploid } \\
\text { karyotype }\end{array}$} & \multicolumn{15}{|c|}{ Chromosome number } & \multirow[b]{3}{*}{ Total } \\
\hline & & \multicolumn{4}{|c|}{$x$} & \multicolumn{4}{|c|}{$Y$} & \multicolumn{3}{|c|}{$\mathrm{XT}+$} & \multicolumn{3}{|c|}{$\mathrm{YT}+$} & $X Y$ & \\
\hline & & 25 & 26 & 27 & 28 & 25 & 26 & 27 & 28 & 25 & 26 & 27 & 25 & 26 & 27 & 28 & \\
\hline$F_{1} 199$ & $54 X Y$ & 0 & 6 & 51 & 1 & 2 & 4 & 35 & 0 & 0 & 0 & 0 & 0 & 0 & 0 & 1 & 100 \\
\hline$F_{1} 49$ & $53 \mathrm{XYt}_{1}$ & 2 & 4 & 22 & 0 & 0 & 3 & 31 & 0 & 2 & 19 & 1 & 1 & 15 & 0 & 0 & 100 \\
\hline$F_{1} 101$ & $53 \mathrm{XYt}_{1}$ & 1 & 1 & 14 & 0 & 0 & 3 & 11 & 0 & 1 & 11 & 3 & 1 & 9 & 1 & 0 & 56 \\
\hline$F_{1} 113$ & $53 X \mathrm{Yt}_{1}$ & 0 & 0 & 2 & 0 & 0 & 3 & 0 & 0 & 0 & 1 & 0 & 0 & 1 & 0 & 0 & 7 \\
\hline Total & & 3 & 5 & 38 & 0 & 0 & 9 & 42 & 0 & 3 & 31 & 4 & 2 & 25 & 1 & 0 & 163 \\
\hline$F_{2} 200$ & $52 X \mathrm{tt}_{1} \mathrm{t}_{\mathrm{l}}$ & 0 & 0 & 0 & 0 & 0 & 0 & 0 & 0 & 0 & 11 & 0 & 1 & 5 & 0 & 0 & 17 \\
\hline
\end{tabular}


The calculated degree of non-disjunction was $4.0 \%$. Since one of the cells showed non-disjunction of the sex chromosomes the autosomal non-disjunction was $2.0 \%$.

Some metaphase spreads were observed with the diploid number of 54XY. These were assumed to be spermatogonia and were of two morphological types. The first had the characteristic appearance of metaphase II chromosomes with widely parted chromatids and elongated centromeric regions whilst the second had the typical appearance of mitotic chromosomes.

Meiotic data from the three heterozygous animals are shown in Table 1. Thirty-seven cells in late diplotene and early diakinesis were photographed and karyotyped (PI. 2, Fig. 4). Each cell contained 26 bodies consisting of 24 autosomal bivalents, the $X-Y$ bivalent and a trivalent of irregular shape which was formed by the translocation chromosome and the two acrocentric homologues of the short and long arms of the translocation chromosome. The mean autosomal chiasma counts were similar to those for Ram $F_{1} 199$ (Table 1).

A total of 163 cells at second metaphase was counted (Table 2) and 98 were photographed and karyotyped. There was no significant difference from a $1: 1$ ratio of $\mathrm{X}$ - and $\mathrm{Y}$-bearing cells $\left(\chi^{2}=0 \cdot 15\right.$; $0.5<P<0.7)$ or for $\mathrm{Xt}_{1}$ or $\mathrm{Yt}_{1}$ cells $\left(\chi^{2}=0.64 ; 0.3<P<0.5\right)$. However, there were significantly more normal cells than cells carrying the translocation $\left(\chi^{2}=5.895 ; 0.01<P<0.02\right)$. The calculated degree of non-disjunction was $6.1 \%$.

The meiotic preparations from the homozygous animal, Ram $F_{2} 200$, contained very few cells at diplotene or diakinesis. Sixteen cells were photographed and karyotyped : each contained 26 bivalents (Pl. 2, Fig. 5). The chiasma frequency of the translocation bivalent was $3 \cdot 8 \pm 0 \cdot 6$ (s.d.), compared to a mean of $3.1 \pm 0.5$ for the trivalent in the heterozygotes.

\section{Discussion}

At pachytene, it was not possible to detect a difference between the normal ram and those carrying the Massey I translocation because the cells were not sufficiently well spread to enable the trivalent to be identified. At diakinesis the trivalent in the heterozygous rams was easily recognized, as was the translocation bivalent in the homozygous ram, which had a conformation similar to that of the metacentric chromosomes.

The major difference between the normal ram and those heterozygous for the Massey I translocation was in the higher percentage non-disjunction at second metaphase in the latter $(6.1 \% \mathrm{com}$ pared with $2 \cdot 0 \%$ ). This is a lower non-disjunction percentage than that of $11.2 \%$ for the 6 animals studied by Chapman \& Bruère (1975). Nevertheless, both sets of results have indicated that more aneuploid secondary spermatocytes were being formed by $53 \mathrm{XYt}_{1}$ rams than by normal animals and the assumption is that this is due to non-disjunction of the translocation trivalent. However, no abnormal karyotypes have been found in preimplantation embryos (Long, 1974, 1977). This may have been because such abnormal embryos had died before the period of examination. If this were the case, it might be reflected in lower lambing percentages. No evidence of this has been found (Bruère $\&$ Chapman, 1974; Bruère, 1975; Long, 1975), but small differences would be difficult to detect. Alternatively, as suggested by Chapman \& Bruère (1975), aneuploid secondary spermatocytes may fail to mature to spermatozoa. Roosen-Runge (1973) has described cell loss in the early stages of spermatogenesis in a number of species and Baranov \& Dyban (1976) found no evidence in mice that numerically unbalanced secondary spermatocytes gave rise to spermatozoa which took part in fertilization. In contrast, Ford \& Evans (1973) have shown that aneuploid zygotes were present in the mice they studied in the same proportion as the aneuploid secondary spermatocytes.

The excess of normal to $t_{1}$-bearing secondary spermatocytes was probably a technical artefact because centromeric separation may have caused a $26 \mathrm{t}_{1}$ cell to be scored as a 27 . Chapman \& Bruère (1975) found approximately equal numbers of euploid normal and balanced translocation cells in their animals and breeding records from $53 \mathrm{XYt}_{1}$ rams have shown a $1: 1$ ratio of normal to $53 \mathrm{t}_{1}$ lambs (Bruère, 1974, 1975; Long, 1975).

The spermatogenic abnormalities in the homozygous ram are extremely interesting. Bruère (1974) described a number of matings, including some of $52 \mathrm{XYt}_{1} \mathrm{t}_{1} \times 54 \mathrm{XX}$ animals: 49 ewes produced 63 
lambs but no data were given on the number of rams or barren ewes. However, Bruère(1974) concluded that the reproductive performance of ewes of normal karyotype mated to $52 X \mathrm{XY}_{\mathrm{t}} \mathrm{t}_{1}$ rams was comparable to the average performance with New Zealand stud Romneys. Chapman \& Bruère (1975) examined meiosis in a $52 \mathrm{XYt}_{1} \mathrm{t}_{1} \mathrm{ram}$; spermatogenesis was normal and the second metaphase data were similar to those of 10 normal rams. In the present study, $R a m F_{2} 200$ was the only homozygote from the $53 \mathrm{XYt}_{1} \times 53 \mathrm{XYt}_{1}$ matings which also produced 7 lambs with a normal karyotype and 3 heterozygous for the Massey I translocation (Long, 1975). In view of spermatogenic abnormalities in this homozygous animal, it is important that the fertility of such animals be more thoroughly investigated.

The work was supported by the Wellcome Trust. I wish to thank Dr A. N. Bruère for providing the 4 New Zealand Romney rams and Dr D. N. Logue for technical information.

\section{References}

Baranov, V.S. \& Dyban, A.P. (1976) Prezygotic selection of male gametes in laboratory mice. Tsitologiya $18,556-559$.

BRUÈre, A.N. (1974) The segregation patterns and fertility of sheep heterozygous and homozygous for three different Robertsonian translocations.J.Reprod. Fert. 41, 453-464.

BRUÈRe, A.N. (1975) Further evidence of normal fertility and the formation of balanced gametes in sheep with one or more different Robertsonian translocations. J. Reprod. Fert. 45, 323-331.

Bruère, A.N. \& Chapman, H.M. (1974) Double translocation heterozygosity and normal fertility in sheep. Cytogenet. Cell Genet. 13, 342-351.

Cattanach, B.M. \& Moseley, H. (1973) Non-disjunction and reduced fertility caused by the tobacco mouse metacentric chromosomes. Cytogenet. Cell Genet. 12, 264-287.

Chapman, H.M. \& Bruère, A.N. (1975) The frequency of aneuploidy in the secondary spermatocytes of normal and Robertsonian translocation-carrying rams. J. Reprod. Fert. 45, 333-342.

COle, H.H. \& CUPPS, P.T. (1959) Reproduction in Domestic Animals, 1st edn, Vol. II. Academic Press, New York.
Ford, C.E. \& Evans, E.P. (1973) Non-expression of genome unbalance in haplophase and early diplophase of the mouse and incidence of karyotypic abnormality in post-implantation embryos. In Les Accidents Chromosomiques de la Reproduction, pp. 271-285. Eds A. Boué \& C. Thibault. INSERM, Paris.

Logue, D.N. (1975) A study of bovine cytogenetics. Ph.D. thesis, University of Glasgow.

LoIR, M.M. (1971) Evolution morphologique des chromosomes meiotiques chez le Belier (Ovis aries). C. r. hebd. Séanc. Acad. Sci., Paris 272, 2587-2590.

LoNG, S.E. (1974) Fertility of sheep with a Robertsonian translocation. Vet. Rec. 94, 161-162.

LoNG, S.E. (1975) An investigation of a centric fusion (Robertsonian) translocation. Ph.D. thesis, University of Glasgow.

LoNG, S.E. (1977) Cytogenetic examination of preimplantation blastocysts of ewes mated to rams heterozygous for the Massey I $\left(t_{1}\right)$ translocation. Cytogenet. Cell Genet. 18, 82-89.

Roosen-RunGe, E.C. (1973) Germinal cell loss in normal metazoan spermatogenesis $J$. Reprod. Fert. 35, 339348.

Received 7 December 1977

\section{EXPLANATION OF PLATES}

\section{PLATE 1}

Karyotypes of celis from the normal 54XY ram, $F_{1} 199$.

Fig. 1. Cell at diakinesis. The arrow indicates the $\mathrm{X}-\mathrm{Y}$ bivalent.

Fig. 2. Cell at second metaphase

Fig. 3. Cell at second metaphase with an $\mathrm{X}$ and a $\mathrm{Y}$ chromosome.

\section{PLATE 2}

Fig. 4. Karyotype of a cell at diakinesis from the $53 \mathrm{XY}_{1} \mathrm{ram}, \mathrm{F}_{1} 101$. The arrow indicates the translocation trivalent.

Fig. 5. Karyotype of a cell at diakinesis from the $52 X Y t_{1} t_{1} r a m, F_{2} 200$. The arrow indicates the translocation bivalent. 


\section{PLATE 1}

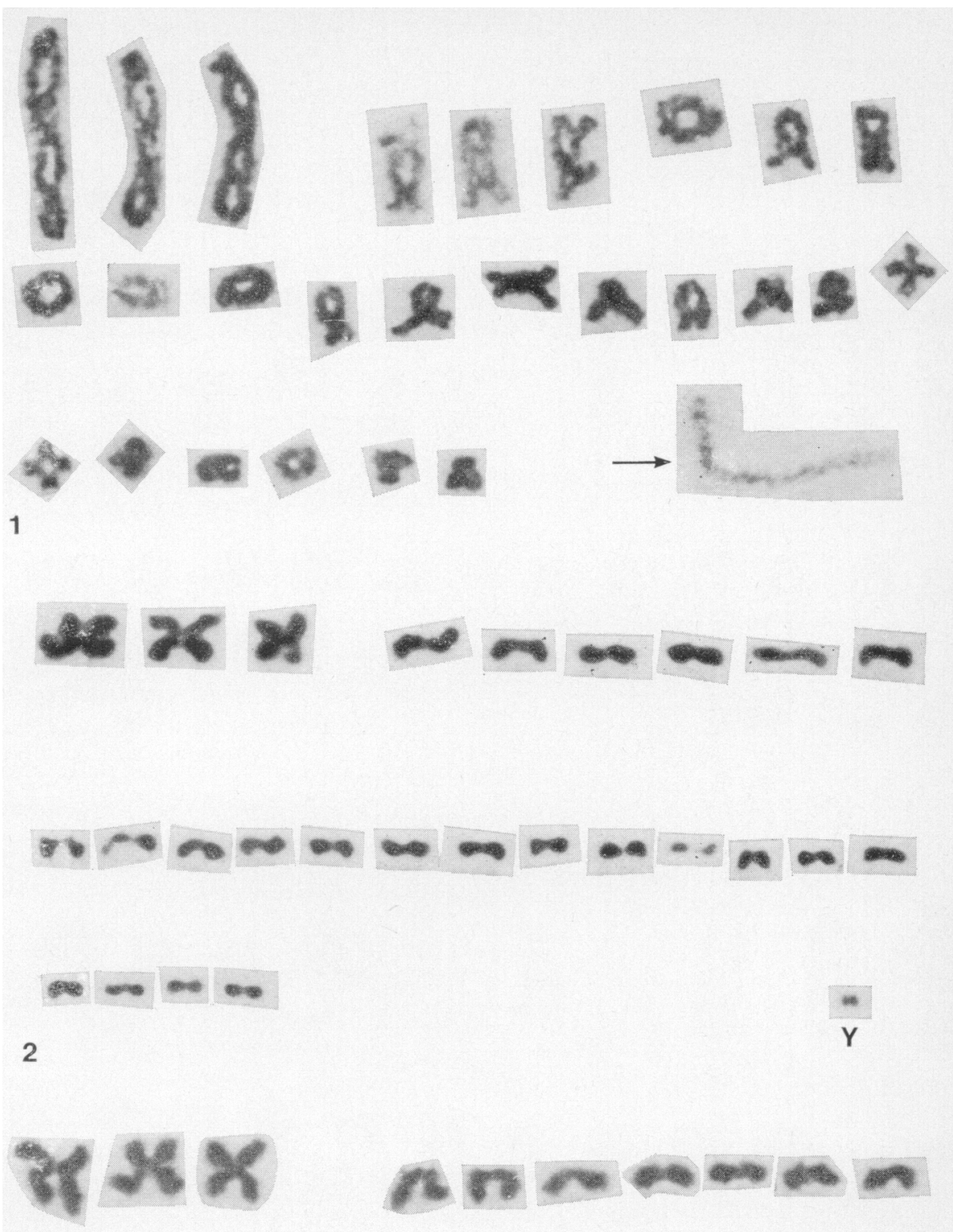

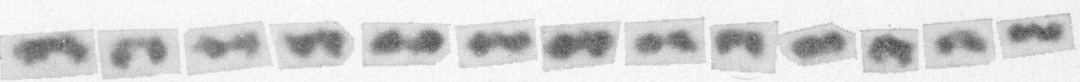

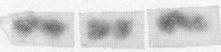

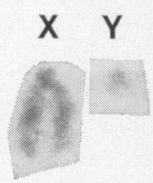


PLATE 2

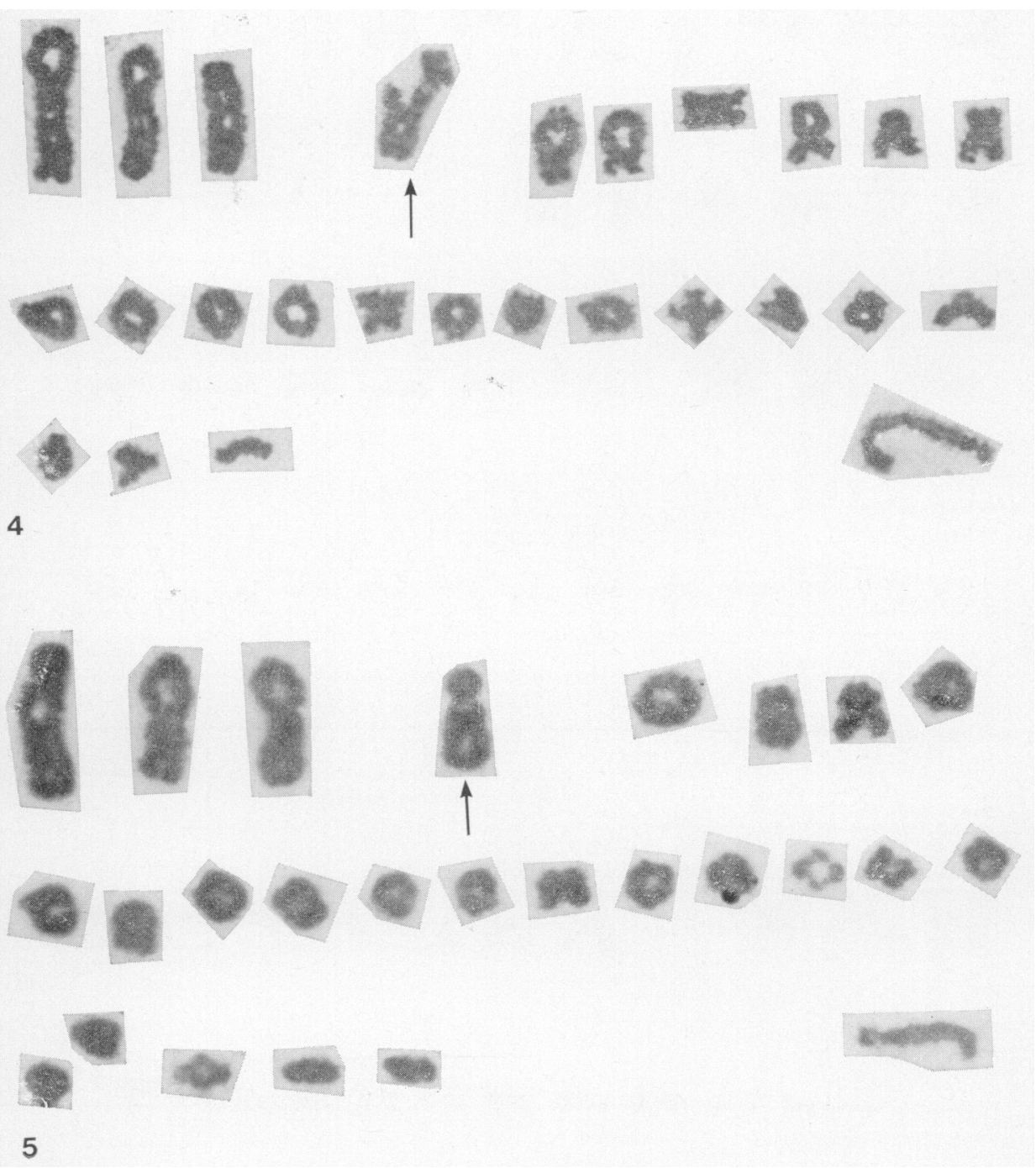

